\title{
"Honrar a Pátria investigando o passado": a narrativa do domínio holandês e a construção do lugar do Rio Grande do Norte na memória nacional ${ }^{1}$
}

\section{"Honoring the homeland by investigating the past": the narrative of Dutch domination and the construction of Rio Grande do Norte's place in national memory}

\author{
Bruno Balbino Aires da Costa ${ }^{*}$ \\ https://orcid.org/0000-0002-6709-8247
}

\begin{abstract}
Resumo
Diante de um cenário de redimensionamento da relação entre o todo (a união) e as partes (os estados), graças à recomposição do federalismo na República, as oligarquias estaduais elaboraram projetos identitários com o interesse de instituir um papel para os estados na construção da memória histórica do Brasil. No limiar da República, letrados e políticos norte-rio-grandenses se preocuparam em urdir narrativas que instituíssem um lugar para o Rio Grande do Norte na elaboração da memória nacional. O interesse por essa questão fez parte das estratégias políticas do grupo familiar que ascendeu ao governo do estado no momento da proclamação da República. Um dos seus representantes, Augusto Tavares de Lyra, esteve comprometido em construir uma nova semântica para o passado do estado. Para isso, publicou o artigo Domínio Hollandez no Brasil, especialmente no Rio Grande do Norte, nos anais do Primeiro Congresso de História Nacional em 1915. Nesse sentido, o presente texto se propõe a investigar de que maneira o supracitado artigo de Augusto Tavares de Lyra contribuiu para a construção de um lugar para o Rio Grande do Norte na formação da memória nacional.
\end{abstract}

Palavras-chave: Domínio Holandês; Memória Nacional; História da Historiografia Norte-rio-grandense.

\begin{abstract}
:
In face of the cenary of the redimensioning the relationship between the whole (the union) and the parties (the states), thanks to the restoration of federalism in the Republic, the state oligarchies elaborated identity projects
\end{abstract}

${ }^{1} \mathrm{O}$ texto apresenta resultados da minha pesquisa de Doutorado em História pela Universidade Federal do Rio Grande do Sul - UFRGS.

${ }^{*}$ Doutor em História pela UFRGS. Professor de História do Instituto Federal de Educação, Ciência e Tecnologia do Rio Grande do Norte (IFRN). E-mail: bruno.aires@ifrn.edu.br 
with the interest of establishing a role for the states in the construction of the historical memory of Brazil. On the threshold of the Republic, Rio Grande do Norte's intellectuals and politicians were concerned with creating narratives that would establish a place for Rio Grande do Norte in the elaboration of national memory. The interest in this issue was part of the political strategies of the family group that ascended to the state government, at the time of the proclamation of the Repubdlic. One of its representatives, Augusto Tavares de Lyra, was committed to building a new semantics for the state's past. To this end, he published the article Domínio Hollandez no Brasil, especialmente no Rio Grande do Norte in the annals of the Primeiro Congresso de História Nacional in 1915. In this sense, this text aims to investigate how the mentioned article by Augusto Tavares de Lyra contributed to the construction of a place for Rio Grande do Norte in the formation of national memory.

Keywords: Dutch domain; National memory; Rio Grande do Norte's History of Historiography

\section{Introdução}

Com o advento da República no Brasil, em 1889, criou-se um novo pacto político alicerçado no acordo entre poder local e o nacional, o que assegurou a unidade federativa por meio de um jogo político, que garantiu a preponderância dos estados mais desenvolvidos. ${ }^{2}$ Embora fosse caracteristicamente política, essa configuração entre os estados e a união não se fez alheia às disputas pelo universo simbólico, mais especificamente pelos usos políticos do passado nacional. Para as oligarquias estaduais, era imperioso instituir discursivamente um lugar, um papel, para os estados na construção da memória histórica do Brasil. Políticos e homens de letras de diversas regiões do país, aos seus modos, produziram narrativas historiográficas para os seus estados a fim de que pudessem contribuir para o redimensionamento desse projeto memorialista.

No limiar da República, letrados e políticos norte-rio-grandenses também se preocuparam em urdir narrativas que instituíssem um lugar para o Rio Grande do Norte na elaboração da memória nacional. ${ }^{3}$ O interesse por essa

\footnotetext{
${ }^{2}$ VISCARDI, Cláudia Maria Ribeiro. 0 teatro das oligarquias: uma revisão da "política do café com leite". 2.ed. Belo Horizonte: Fino Traço, 2012. p. 52.

${ }^{3}$ Conferir: COSTA, Bruno Balbino Aires da Costa. "A casa da memória norte-rio-grandense": o Instituto Histórico e Geográfico do Rio Grande do Norte e a construção do lugar do Rio Grande do Norte na memória nacional (1902-1927). Tese (Doutorado em História) - Programa de Pós-graduação em História, Universidade Federal do Rio Grande do Sul, Porto Alegre. 2017
} 
questão fez parte das estratégias políticas do grupo familiar que ascendeu ao governo do estado no momento da Proclamação da República: os Albuquerque Maranhão - liderados por Pedro Velho. No final do século XIX e início do XX, a família Albuquerque Maranhão concebeu e mobilizou estratégias discursivas para a produção da identidade histórica, territorial e étnica do Rio Grande do Norte. ${ }^{4}$ Como corolário desse agenciamento prevaleceu no estado "um forte apelo nativista, o orgulho de ter nascido e ser rio-grandense-do-norte, sentimento que, para muitos, a Monarquia teimava em desconsiderar". ${ }^{5} \mathrm{Nesse}$ sentido, com a República e com ela a chegada dos Albuquerque Maranhão ao poder, o passado do Rio Grande do Norte tornou-se objeto de preocupação por parte do grupo dominante. É este grupo que se lança na construção das bases da identidade histórica do estado.

Um dos principais membros da família Albuquerque Maranhão, comprometido em construir uma nova semântica para o passado do Rio Grande do Norte, foi Augusto Tavares de Lyra. Nascido em 1872, na cidade de MacaíbaRN, Tavares de Lyra ocupou vários cargos da vida pública do Rio Grande do Norte e do Brasil. ${ }^{6}$

Além de político, Tavares de Lyra também se enveredou pelo mundo das letras. Formou-se em ciências jurídicas e sociais pela Faculdade de Direito do Recife (FDR) em 1892. Tal posição permitiu-lhe lecionar, a partir de 1897, em um dos principais grupos escolares do estado: o Atheneu norte-rio-grandense. Além disso, Augusto Tavares de Lyra foi um dos fundadores do Instituto Histórico e Geográfico do Rio Grande do Norte (IHGRN), criado em Natal, no dia 29 de março de $1902 .{ }^{7}$ Cinco anos depois de participar da fundação do IHGRN, o

\footnotetext{
${ }^{4}$ Para compreender as estratégias espaciais das elites norte-rio-grandenses do início do século XX, conferir: PEIXOTO, Renato Amado. Espacialidades e estratégias de produção identitária no Rio Grande do Norte no início do século XX. In: PEIXOTO, Renato Amado (org.). Nas trilhas da representação: trabalhos sobre a relação entre história, poder e espaços. Natal: EDUFRN, 2012. p.13-36

${ }^{5}$ BUENO, Almir de Carvalho. Visões de República: ideias e práticas políticas no Rio Grande do Norte (18801895). Natal: EDUFRN, 2002. p.93.

${ }^{6}$ Tavares de Lyra atuou em várias esferas do poder público. Nos primeiros anos da nascente República brasileira foi deputado federal, governador do estado do Rio Grande do Norte, senador da República, ministro da Justiça e Negócios Interiores, ministro da Viação e obras públicas, ministro de Estado por duas vezes e ministro do tribunal de contas da União. A maior parte desses cargos públicos foi exercida por ele nas duas primeiras décadas do século XX. Em grande medida, o que lhe credenciou para a vida política foi a sua relação de parentesco com Pedro Velho de Albuquerque Maranhão, o primeiro governador do estado do Rio Grande do Norte e líder do Partido Republicano norte-rio-grandense, do qual Tavares de Lyra era genro. Sua relação de parentesco com a família Albuquerque Maranhão lhe rendeu o subsídio para a atuação no cenário político do Estado, chegando ao cargo de Governador em 1904.

${ }^{7}$ Acta da installação do Instituto Histórico e Geographico do Rio Grande do Norte. Revista do Instituto Histórico e Geográfico do Rio Grande do Norte. n. 1. Volume 1. Natal, 1903.
} 
historiador norte-rio-grandense se tornou sócio correspondente do Instituto Histórico e Geográfico Brasileiro (IHGB). ${ }^{8}$

Ao longo de sua atividade intelectual no IHGB, Tavares de Lyra escreveu vários artigos para a revista da agremiação e participou de comitivas de organização dos Congressos de História Nacionais de 1914, 1931 e 1938, presidindo os dois últimos (1938 e 1949). ${ }^{9}$ Nesse percurso intelectual, o historiador norte-rio-grandense escreveu livros de natureza historiográfica, jurídica, geográfica e biográfica, tendo como principais temas a história política e administrativa do Rio Grande do Norte e do Brasil.

Augusto Tavares de Lyra foi um dos intelectuais norte-rio-grandenses interessados em evidenciar o papel do seu estado na memória histórica do país. Seu artigo intitulado Domínio Hollandez no Brasil, especialmente no Rio Grande do Norte, publicado nos anais do Primeiro Congresso de História Nacional (PCHN) em 1915, demonstra esse esforço.

O presente texto se propõe a investigar de que maneira o supracitado artigo de Augusto Tavares de Lyra contribuiu para a construção de um lugar para o Rio Grande do Norte na formação da memória nacional. Para a consecução desse objetivo, dividi o texto em duas partes: na primeira, tratei das condições de possibilidade do artigo de Tavares de Lyra, evidenciando a articulação do seu texto com as atividades intelectuais desenvolvidas pelo IHGB, especificamente o PCHN; na segunda, analisei o artigo propriamente dito, assinalando as estratégicas discursivas do intelectual potiguar na formação de determinadas representações do passado norte-rio-grandense.

\section{O Primeiro Congresso de História Nacional: nacionalismo e escrita da História}

Realizado entre 7 e 16 de setembro de 1914, na cidade do Rio de Janeiro, o PCHN foi organizado pelos sócios do IHGB cujo interesse principal era a promoção de um evento científico dedicado ao estudo da história do Brasil. ${ }^{10}$ Conforme Lúcia Paschoal Guimarães, devido à ausência de ambiente universitário no país, coube às associações científicas e aos redutos letrados a

\footnotetext{
${ }^{8}$ Revista do Instituto Histórico e Geográfico Brasileiro Tomo LXX. Rio de Janeiro, 1907, p.928. Tavares de Lyra foi sócio correspondente de vários Institutos Históricos espalhados pelo Brasil, bem como sócio efetivo da Sociedade Nacional de Geografia, e fundador da Sociedade de Direito Internacional.

${ }^{9}$ Revista do Instituto Histórico e Geográfico Brasileiro. Volume 241. Rio de Janeiro, 1958, p.2.

${ }^{10}$ GUIMARÃES, Lúcia Maria Paschoal. Da escola palatina ao silogeu: Instituto Histórico e Geográfico Brasileiro (1889-1938). Rio de Janeiro: Museu da República, 2007. p.80.
} 
realização de congressos e simpósios, destinados à reflexão, à circulação de ideias e à promoção de atividades intelectuais. ${ }^{11}$ Participante de vários congressos estrangeiros na área dos estudos históricos, o IHGB teve a iniciativa pioneira de realizar um evento científico no Brasil, marcadamente voltado para o âmbito da história. ${ }^{12}$

Desde 1903, já havia a proposta de organização de um Congresso Histórico no IHGB, esboçada pelos membros Affonso Arinos de Mello Franco, João Mendes de Almeida Júnior e Luiz Antônio Ferreira Gualberto. ${ }^{13}$ De acordo com Lúcia Paschoal Guimarães, tal proposição não logrou êxito por causa das próprias circunstâncias políticas e econômicas enfrentadas pelo IHGB no limiar da experiência republicana. ${ }^{14}$ Todavia, apenas em 1913 é que Oliveira Lima colocava em prática o projeto de 1903, propondo ao IHGB a realização do Primeiro Congresso de História Nacional em 1914, sendo, prontamente, acatado pela instituição. ${ }^{15}$ É preciso assinalar que as condições políticas e econômicas vivenciadas pelo IHGB, a partir da década de 1910, já eram outras em relação ao período inicial da experiência republicana. ${ }^{16}$ Além disso, uma onda de nacionalismo impregnou o ambiente intelectual brasileiro, especialmente o IHGB, durante a Grande Guerra (1914-1918). ${ }^{17}$

A Primeira Guerra Mundial foi um divisor de águas na questão nacional no Brasil e em toda a América Latina a partir da década de $10 .{ }^{18}$ Com a irrupção do conflito mundial, o nacionalismo foi trazido à ordem do dia - concomitantemente ao questionamento da tradição e dos valores europeus e as transformações dos padrões culturais depois da decadência da Europa pós-Guerra

\footnotetext{
${ }^{11}$ GUIMARÃES, Lúcia Maria Paschoal. Primeiro Congresso de História Nacional: breve balanço da atividade historiográfica no alvorecer do século XX. Tempo. Revista do Departamento de História da UFF, Niterói (RJ), v. 9, n.18, 2005, p.2-3.

${ }^{12}$ Ibidem, p.3.

${ }^{13}$ ACTA DA SEGUNDA SESSÃO ORDINARIA EM 30 DE MAIO DE 1913. In: Revista do Instituto Histórico e Geográfico Brasileiro. Rio de Janeiro. Parte II. Tomo LXXVI. 1913. p.505.

${ }^{14}$ GUIMARÃES, Lúcia Maria Paschoal. Da escola palatina ao Silogeu. op. cit., p.80-81.

${ }^{15}$ ACTA DA SEGUNDA SESSÃO ORDINARIA EM 30 DE MAIO DE 1913. In: Revista do Instituto Histórico e Geográfico Brasileiro. Rio de Janeiro. Parte II. Tomo LXXVI. 1913. p.505.

${ }^{16}$ GUIMARÃES, Lúcia Maria Paschoal. Da escola palatina ao Silogeu. op. cit., p.33.

${ }^{17}$ HRUBY, Hugo. Obreiros diligentes e zelosos auxiliando no preparo da grande obra: a História do Brasil no Instituto Histórico e Geográfico Brasileiro (1889-1912). Dissertação (Mestrado em História). Faculdade de Filosofia e Ciências Humanas, PUCRS. Porto Alegre. 2007. p.210.

${ }^{18} \mathrm{Cf}$. WASSERMAN, Cláudia. Percurso Intelectual e Historiográfico da Questão nacional e Identitária da América Latina: as condições de produção e o processo de repercussão do conhecimento histórico. In: Revista Anos 90, Porto Alegre, n.18, dezembro de 2003. pp. 99-123.
} 
- afirmando a necessidade de pensar o Brasil do ponto de vista dos brasileiros. ${ }^{19}$ Homens de letras como Olavo Bilac, Rodrigo Otávio, Alberto Torres, Manuel Bonfim, Álvaro Bomilcar, Afonso Celso, dentre outros, defendiam concepções comprometidas com os valores da cultura nacional, como a formação da identidade da nação, o que levou a uma releitura da tradição, ou seja, a releitura da interpretação histórica - muito embora, nem todos os letrados da Primeira República tivessem adotado a mesma postura nacionalista. ${ }^{20} \mathrm{Como}$ corolário dessa nova leitura e interpretação da nação, reafirmaram-se os sentimentos cívicos à medida que crescia o apostolado do patriotismo. ${ }^{21} \mathrm{Essa}$ nova configuração da questão nacional afetou significativamente a produção literária e historiográfica brasileira nas décadas de 10 e $20 .^{22}$

A partir de 1912, a Trindade do Silogeu23 composta por Afonso Celso, Max Fleiüss e Ramiz Galvão deu à administração do IHGB um novo rumo intelectual, preocupada com o perfil acadêmico do quadro social e o interesse pela produção historiográfica voltada às questões nacionais. Segundo Lúcia Maria Paschoal Guimarães, a consciência cívica mobilizou as elites intelectuais na década de 1910, implicando na escrita de uma história pragmática, "voltada para o cultivo das virtudes cívicas e reverência aos valores do passado, assim como às figuras notáveis da história do Brasil, que deveriam servir de modelo para as novas gerações". ${ }^{24}$ Por meio da realização e organização dos Congressos de História Nacional em 1914, 1931, 1938 e 1949, bem como a publicação do Dicionário Histórico, Geográfico e Etnográfico do Brasil (DHGEB) e as comemorações do centenário da Independência do Brasil em 1922, o IHGB, administrado pela chamada Trindade do Silogeu, inseria-se naquela onda de culto à nacionalidade, de ebulição do catecismo cívico e efervescência do patriotismo que pretendia desvendar o Brasil aos brasileiros pelo caminho das letras, mais detidamente, pelo estudo da história da Pátria. ${ }^{25}$ Nesse sentido, deve-se considerar a realização do Primeiro Congresso de História Nacional e, por conseguinte, a produção historiográfica dela decorrente como parte integrante do conjunto de atividades intelectuais desenvolvidas no e pelo IHGB nas duas primeiras décadas

\footnotetext{
${ }^{19}$ OLIVEIRA, Lúcia Lippi. A questão nacional na Primeira República. São Paulo: Editora Brasiliense, 1990. p.126.

${ }^{20}$ De acordo com Lúcia Lippi, o nacionalismo conservador, defendido por Eduardo Prado e Afonso Celso, por exemplo, era diferente da abordagem e do estilo do nacionalismo republicano "jacobino". Cf. OLIVEIRA, Lúcia Lippi. A questão nacional na Primeira República. op. cit.

${ }^{21}$ GUIMARÃES, Lúcia Maria Paschoal. Primeiro Congresso de História Nacional. op. cit., 2005.

${ }^{22}$ Cf. GOMES, Ângela de Castro. A República, a História e o IHGB. Belo Horizonte: Argvmentvm, 2009.

${ }^{23}$ GUIMARÃES, Lúcia Maria Paschoal. Da escola palatina ao Silogeu. op. cit,, p.198

${ }^{24}$ Ibidem, p.198.

${ }^{25}$ Ibidem, p.81.
} 
do século XX, voltadas para a manifestação nacionalista e cívica a partir da pesquisa e da escrita da história.

Apesar da chancelaria do congresso nacional, o IHGB não monopolizou a produção intelectual a ser publicada nos anais. Pelo contrário, os sócios dos institutos históricos dos estados e/ou os representantes dos governadores foram convocados para contribuírem com a publicação de textos relativos à história do Brasil. ${ }^{26}$ Isso demonstra, em parte, o interesse do IHGB em se aproximar dos institutos históricos espalhados pelo país e garantir certa unidade entre os diferentes entes da federação. A cultura cívica, o nacionalismo e os interesses políticos mais centralistas ressaltavam a configuração de um ambiente voltado para a unidade nacional em detrimento dos regionalismos estaduais. É por essa razão que a comissão executiva do PCHN enviou vários ofícios aos governadores das unidades federativas da nação, solicitando que apoiassem a sua realização, e convites aos letrados inscritos nos estados que "notoriamente" tinham se ocupado dos assuntos históricos, para tomarem parte no referido evento, na condição de delegados estaduais. ${ }^{27}$

Embora não tivesse sido escolhido como delegado do Rio Grande do Norte, Augusto Tavares de Lyra não ficou de fora da organização do congresso. Com Homero Baptista e Almirante Índio do Brasil, o político e intelectual potiguar foi nomeado para compor a Comissão Central do PCHN..$^{28}$ Nesse período, Augusto Tavares de Lyra ocupava o cargo de Senador da República, o que levou os sócios do IHGB a enviar-lhe uma carta pedindo-lhe que solicitasse ao Senado um auxílio financeiro para a realização do referido congresso. ${ }^{29}$

A função de Augusto Tavares de Lyra na comissão executiva do congresso de História foi coordenar a seção de História parlamentar. As teses submetidas ao evento foram organizadas de acordo com as subdivisões temáticas das seções, a saber: História Geral, História Constitucional e Administrativa,

\footnotetext{
${ }^{26}$ ACTA DA SEGUNDA SESSÃO ORDINARIA EM 30 DE MAIO DE 1913. In: RIHGB. Rio de Janeiro. Parte II. Tomo LXXVI. 1913. p.505.

${ }^{27}$ ACTA DA PRIMEIRA SESSÃO PREPARATÓRIA DA COMMISSÃO EXECUTIVA, EM 5 DE JUNHO DE 1913. In: Revista do Instituto Histórico e Geográfico Brasileiro. Rio de Janeiro. Parte I. Tomo especial. 1915. p.6. A comissão executiva teria em cada estado, dois delegados, investidos do encargo de auxiliar a Comissão Central do congresso. Os delegados do Rio Grande do Norte foram: Vicente de Lemos e Luiz Fernandes, ambos sócios do Instituto Histórico e Geográfico do Rio Grande do Norte. ACTA DA TERCEIRA SESSÃO PREPARATÓRIA DA COMMISSÃO EXECUTIVA, EM 27 DE JUNHO DE 1913. In: Revista do Instituto Histórico e Geográfico Brasileiro. Rio de Janeiro. Parte I. Tomo especial. 1915. p.7.

${ }^{28}$ ACTA DA SESSÃO PREPARATÓRIA DA COMMISSÃO EXECUTIVA, EM 24 DE JANEIRO DE 1914. In: Revista do Instituto Histórico e Geográfico Brasileiro. Rio de Janeiro. Parte I. Tomo especial. 1915.p.21.

${ }^{29}$ Idem, p.22. É provável que a sua nomeação para Comissão Central estivesse vinculada à sua posição nas esferas do poder político e a sua capacidade de mobilizar alguns auxílios financeiros para o evento.
} 
História Parlamentar, História Econômica, História Militar, História Literária e das Artes, História das Explorações Geográficas, Histórias das Explorações Arqueológicas e Etnográficas e História Diplomática. Havia uma espécie de ementa para orientar a apresentação dos trabalhos. ${ }^{30}$ Entretanto, a contribuição de Augusto Tavares de Lyra ao congresso não se encerrou apenas na coordenação da seção História parlamentar. Ao lado de Eloy Castriciano de Souza, Augusto Tavares de Lyra foi nomeado pelos delegados do Rio Grande do Norte para ser um dos representantes do governo e do IHGRN no Congresso de História Nacional, publicando em seus anais o artigo Domínio Hollandez no Brasil, especialmente no Rio Grande do Norte. ${ }^{31}$

Em uma carta endereçada ao seu amigo e delegado do Rio Grande do Norte, Vicente de Lemos, Augusto Tavares agradece a escolha, ressaltando que desejava "dar uma prova de que, em nosso Instituto ahi se estuda um pouco e se procura honrar a Patria, investigando o passado". ${ }^{32}$ A menção a honrar a Pátria diz respeito ao croquis apresentado pelo Sr. Adalberto de Mattos para a confecção da medalha do congresso. ${ }^{33} \mathrm{~A}$ escolha da legenda pela comissão executiva do PCHN estava diretamente relacionada ao culto cívico e ao patriotismo, tão presentes na produção intelectual dos sócios do IHGB. O artigo de Augusto Tavares de Lyra não foi diferente. O texto Domínio Hollandez no Brasil, especialmente no Rio Grande do Norte foi urdido sob o signo do nacionalismo.

Apesar de coordenar a seção História Parlamentar, o artigo de Augusto Tavares de Lyra foi lido e publicado na seção História Geral. A razão é simples: o texto do intelectual norte-rio-grandense era incompatível com o programa da História Parlamentar. O foco temático e temporal da seção consistia na história política do Império, especialmente voltado para questões referentes à dinâmica do poder na experiência monárquica brasileira, o que era incompatível

\footnotetext{
${ }^{30}$ Com o intuito de organizar as teses apresentadas no Primeiro Congresso de História Nacional, a Comissão Central dividiu-as em nove seções: História Geral, História Constitucional e Administrativa, História Parlamentar, História Econômica, História Militar, História Literárias e das Artes, História das Explorações Geográficas, Histórias das Explorações Arqueológicas e Etnográfica e História Diplomática. ACTA DA SESSÃO PREPARATÓRIA DA COMMISSÃO EXECUTIVA, EM 11 DE FEVEREIRO DE 1914. In: Revista do Instituto Histórico e Geográfico Brasileiro. Rio de Janeiro. Parte I. Tomo especial. 1915.p. 21.

${ }^{31}$ ACTA DA DECIMA TERCEIRA SESSÃO PREPARATÓRIA, EM 4 DE ABRIL DE 1914. In: Revista do Instituto Histórico e Geográfico Brasileiro. Rio de Janeiro. Parte I. Tomo especial. 1915. p.31.

${ }^{32}$ [Carta de Augusto Tavares de Lyra ao Desembargador Vicente Lemos]. In: MEDEIROS, Tarcísio. Augusto Tavares de Lyra, o amigo do meu avô. In: Revista do Instituto Histórico e Geográfico do Rio Grande do Norte. Natal. Volume LII. 1959. p.67

${ }^{33} \mathrm{Na}$ ocasião, foi pedido a ele que oferecesse mais croquis, muito embora o primeiro desenho tenha interpretado fielmente a legenda adotada para o evento: Priora disquirendo Patriam colimus - Honramos a Pátria investigando o passado. ACTA DA SESSÃO PREPARATÓRIA DA COMMISSÃO EXECUTIVA, EM 11 DE FEVEREIRO DE 1914. In: Revista do Instituto Histórico e Geográfico Brasileiro. Rio de Janeiro. Parte I. Tomo especial. 1915.
} 
com a proposta do artigo de Augusto Tavares de Lyra. Nesse sentido, o tema do domínio holandês era objeto de outra seção, voltada para os estudos gerais da história do Brasil.

O programa organizado por Manoel Cícero Peregrino, presidente da seção História Geral, contemplava os grandes acontecimentos da memória histórica da nação. Assim como a seção História Parlamentar, a História Geral estava inserida no campo da história política, demonstrando certa sintonia com as principais tendências da historiografia europeia dos séculos XIX e início do XX. ${ }^{34}$ Contudo, diferentemente da seção História parlamentar, a História Geral abarcava os dois grandes eixos temáticos do estudo da História Geral do Brasil: a Colônia e o Império. ${ }^{35}$ Desde o início da proposta do PCHN, o recorte temporal foi delimitado. Nesse caso, as memórias apresentadas no evento deveriam abordar temas de qualquer período da história brasileira, compreendido desde o descobrimento até a lei da libertação dos nascituros, isto é, de 1500 a $1871 .{ }^{36}$ De acordo com Lúcia Maria Paschoal Guimarães, a escolha desse recorte cronológico pelos organizadores do congresso se fez a partir da noção de distanciamento temporal, a qual o historiador deveria analisar os fatos com isenção, mantendo a coerência com a tradição do IHGB de não estudar episódios recentes da história política do país, evitando-se "tratar de acontecimentos localizados no espaço de tempo compreendido entre a queda da monarquia e o advento do regime republicano". ${ }^{37}$ Inscrito entre a Colônia e o Império, o foco temático da seção História Geral não residiu na organização da estrutura política do Brasil em si, mas sim nos fatos gerais que demarcaram as sucessivas etapas da evolução da sociedade brasileira no tempo. ${ }^{38}$ É por esse motivo que o artigo Domínio Hollandez no Brasil, especialmente no Rio Grande do Norte, de Augusto Tavares de Lyra foi apresentado na seção História Geral. Passo a examiná-lo.

\footnotetext{
${ }^{34}$ GUIMARÃES, Lúcia Maria Paschoal. Primeiro Congresso de História Nacional. op. cit., p.7.

${ }^{35}$ Ibidem, p.8.

${ }^{36}$ ACTA DA PRIMEIRA SESSÃO PREPARATÓRIA DA COMMISSÃO EXECUTIVA, EM 5 DE JUNHO DE 1913. In: Revista do Instituto Histórico e Geográfico Brasileiro. Rio de Janeiro. Parte I. Tomo especial. 1915. p.4.

${ }^{37}$ GUIMARÃES, Lúcia Maria Paschoal. Da escola palatina ao Silogeu. op. cit., p.82.

${ }^{38}$ Ibidem, p.82
} 


\section{Augusto Tavares de Lyra e a construção da narrativa sobre o Domínio Holandês}

Augusto Tavares de Lyra escreveu o texto mais completo, até então, sobre a presença holandesa no Rio Grande. Não é por acaso que José Honório Rodrigues considera seu artigo, intitulado Domínio Hollandez no Brasil, especialmente no Rio Grande do Norte, como sendo o melhor trabalho sobre as lutas holandesas no Rio Grande [do Norte]. ${ }^{39}$

O uso da expressão domínio holandês não era desinteressado, antes, sugere uma interpretação da história. Ao utilizar-se do conceito domínio o autor está aplicando-o de modo significativo, permitindo que o seu leitor compreenda o seu texto, ou melhor, sua interpretação do passado, a partir do emprego de um termo comum, partilhado entre ambos. Em outras palavras, a narrativa pressupõe da parte do narrador e de seu auditório uma familiaridade com expressões empregadas pelo primeiro, construindo uma relação de intersignificação e, por conseguinte, possibilitando ao segundo a compreensão narrativa ${ }^{40}$ Ademais, a expressão domínio holandês propõe uma forma de olhar o passado para além da referência à conquista, do acontecimento histórico per se, colocando-se também como uma percepção temporal. Isso quer dizer que a mencionada expressão diz respeito a uma dada ordem do tempo. Em outros termos, Augusto Tavares de Lyra está sinalizando aos seus leitores que o artigo se refere à experiência da capitania do Rio Grande no tempo, no caso, o período da presença holandesa no Brasil. 0 artigo de Tavares de Lyra é uma forma de fixar o lugar do Rio Grande do Norte em um dos principais acontecimentos históricos do país. A narrativa de Augusto Tavares de Lyra sobre o domínio holandês no Rio Grande [do Norte] afirma a participação do singular coletivo, isto é, do povo norte-rio-grandense, na memória histórica nacional. Desse modo particular, o enredo articula o tempo do Rio Grande do Norte ao tempo da nação. Dito de outra maneira, Augusto Tavares de Lyra urde uma narrativa que reconfigura a escala, isto é, o autor parte do todo abrangente (domínio holandês no Brasil) para relatar o particular (domínio holandês no Rio Grande [do Norte]). É, nesse aspecto, que o tempo da nação e o tempo da capitania encontram-se alinhados.

\footnotetext{
${ }^{39}$ RODRIGUES, José Honório. Historiografia e bibliografia do domínio holandês no Brasil. Rio de Janeiro: Departamento de Imprensa Nacional. 1949.p.134. Coloquei [do Norte] entre colchetes para se referir ao momento da capitania. Considero anacrônico tratar a capitania como Rio Grande do Norte, uma vez que esta menção se deu a posteriori. Doravante, utilizarei o termo Rio Grande [do Norte] com colchetes para identificar uma nomenclatura própria do período referente à capitania.

${ }^{40}$ RICÆEUR, Paul. Tempo e narrativa. A intriga e a narrativa histórica. Volume 1. São Paulo: Editora WMF Martins Fontes, 2010. p.98.
} 
Em relação à narrativa em si, Augusto Tavares de Lyra começa seu texto tratando do problema geral do suposto abandono do Brasil e o seu iminente resultante: a presença de invasores em seu território. É válido destacar que o uso do conceito invasor não era uma novidade. Francisco Adolfo de Varnhagen foi o primeiro a utilizar esse conceito para se referir ao domínio holandês. Para ele, o Brasil teria nascido no "Descobrimento" português, em 1500 , construindo a ideia de que "não haveria história antes da chegada dos portugueses, de forma que as raízes ibéricas estariam realmente no núcleo da identidade brasileira. " ${ }^{41}$ A tese varnhageana desconsiderava, nesse sentido, a presença da história entre os índios, já que eram concebidos como "povos na infância”, destituídos de civilização. ${ }^{42}$ Esse modelo lusófilo de interpretação, que compreende o Brasil como uma extensão do Império Português, além de desconsiderar os povos indígenas, implicou na formulação de uma certa negatividade em relação à entrada de outros povos europeus, especialmente, os holandeses, no território da colônia portuguesa, "considerada uma legítima "invasão"." ${ }^{43}$ O holandês é considerado um invasor. É com essa chave de leitura que Vanhagen elabora sua interpretação sobre o período do domínio neerlandês no Brasil.

Sem sombra de dúvida, Tavares de Lyra apropriou-se não só da narrativa de Francisco Adolfo de Varnhagen, mas também de sua perspectiva quanto ao holandês. Assim como Visconde Porto Seguro, o uso do termo invasor atravessa todo o texto, possuindo uma significação claramente pejorativa. O invasor é o outro que usurpa, depreda, rouba e destrói os bens da Pátria - tanto no sentido da nação como um todo, como no aspecto mais particular, a capitania do Rio Grande. ${ }^{44}$ A despeito das suas ações danosas, as invasões produziram elementos positivos, segundo Augusto Tavares de Lyra: "foi-se conhecendo a terra, percorrendo o extenso litoral, praticando as barras e portos, obtendo-se roteiros seguros para a navegação". ${ }^{45}$ Contudo, a obra geral da invasão é avaliada negativamente:

\footnotetext{
${ }^{41}$ COSTA, Regina de Carvalho Ribeira da. O paradigma das "invasões holandesas": a interpretação de Francisco Adolfo de Varnhagen. Revista do Instituto Histórico e Geográfico Brasileiro, Rio de Janeiro, a.180 (480): 91-120, 2019, p.94

${ }^{42}$ VARNHAGEN, Francisco Adolfo. História Geral do Brazil. Tomo segundo. Rio de Janeiro: E. e H. Laemmert, 1857. p.30.

${ }^{43}$ COSTA, Regina de Carvalho Ribeira da. O paradigma das "invasões holandesas": a interpretação de Francisco Adolfo de Varnhagen. Revista do Instituto Histórico e Geográfico Brasileiro, Rio de Janeiro, a.180 (480): 91-120, 2019, p.96

${ }^{44}$ LYRA, Augusto Tavares de. Dominio Hollandez no Brasil, especialmente no Rio Grande do Norte. In: Revista do Instituto Histórico e Geográfico Brasileiro. Rio de Janeiro. Parte I. Tomo especial. 1915. p.440.

${ }^{45}$ Idem, p.439.
} 
Os inglezes não chegaram a exercer jurisdicção territorial effectiva; mas de suas façanhas, que culminaram nas crueldades de Thomaz Cavendish, nos ficaram tristes e dolorosas.

Com os francezes, que chegaram a constituir perigo serio á consolidação do dominio portuguez, tivemos de medir as nossas armas, expulsando-os pela força, do sul e do norte.

De todos, porém, os que mais fundamente perturbaram a obra da conquista foram os hollandezes, em cuja expulsão se desenvolveram prodigios de valor e de coragem, em combates gloriosos e inolvidaveis. A luta foi desigual, porque, emquanto elles, á sombra de grandes recursos militares, arriscavam apenas o campo de que se haviam apossado para a exploração e para rapinagem, os nossos antepassados tudo empenhavam - honra, familia, bens, vida e patria. Não temos, entretanto, o direito de maldizel-a, porque ao usurpador devemos alvorecer, entre nós, do sentimento de nacionalidade, cuja primeira affirmação se fez, vivaz e indomita, nessa campanha longa, penosa, cheia de indizíveis sacrifícios, que durou mais de vinte annos (...). ${ }^{46}$

Tavares de Lyra afirma que os invasores do Brasil - ingleses, franceses e holandeses -, em maior ou menor proporção, trouxeram sérios agravos à população colonial e ao território brasileiro. Todavia, o autor elege os holandeses como sendo os principais perturbadores da obra da conquista portuguesa. O realce à figura do usurpador holandês é contrastado com a capacidade dos antepassados em lutar contra o domínio do adventício. Há um claro interesse em construir uma identificação entre os brasileiros do presente (contemporâneos ao intelectual norte-rio-grandense) com aqueles que resistiram ao domínio dos povos adventícios.

Ao mencionar a resistência aos invasores, Augusto Tavares de Lyra utiliza-se dos pronomes, pessoal e possessivo, da primeira pessoa do plural. Dessa forma, em contraposição à exploração e à rapinagem dos invasores, os nossos antepassados são descritos como honrosos e empenhados nos valores da família, dos bens e da pátria. Os nossos aí dizem respeito aos habitantes da capitania do Rio Grande à época do domínio holandês, considerados por Tavares de Lyra como seus patrícios do passado, isto é, norte-rio-grandenses. Embora o gentílico norte-rio-grandense não existisse no período colonial, Tavares de Lyra faz questão de construir uma ligação identitária entre os habitantes da capitania do Rio Grande e os cidadãos do seu estado. A intenção do intelectual

${ }^{46}$ Idem. p.440. Gostaria de esclarecer que em todo o trabalho mantive a grafia original dos textos-fontes com o intuito de preservar a cor local do período em que os documentos foram produzidos. 
potiguar é clara: instituir um lugar para o Rio Grande do Norte na memória histórica da nação. Para isso, fazia-se necessário conectar o passado da capitania ao presente do Rio Grande do Norte.

É interessante ressaltar também que a defesa dos valores, família, propriedade e pátria, era bem evidente no início do século XX. São conceitos que circulam com uma certa regularidade e relevância na sociedade que estava experienciando a Grande Guerra. Augusto Tavares de Lyra está justamente salientando a existência desses valores, tão caros ao seu presente, já no passado, a partir de uma narrativa que insiste em construir uma interpretação do pertencimento e da identidade histórica. Ademais, mesmo a despeito do prejuízo causado pelos usurpadores, segundo o intelectual norte-rio-grandense, a obra da invasão e do domínio forjou o sentimento de nacionalidade pelos patriotas. ${ }^{47}$ Esse é um ponto capital do texto de Augusto Tavares de Lyra.

Decerto, o tom do nacionalismo contribuiu para que o letrado norte-rio-grandense interpretasse a luta contra os batavos como uma expressão do sentimento de nacionalidade. Todavia, é importante assinalar que, desde o segundo volume da História Geral do Brazil (1857) de Varnhagen, parte da historiografia brasileira considerava o referido acontecimento histórico como uma demonstração da nacionalidade. Em contrapartida, alguns intelectuais pernambucanos do século XIX, ligados ao discurso nativista, interpretavam o período holandês como um fator diferencial de sua identidade regional, associando-o até mesmo ao discurso separatista e à inclinação à causa republicana - considerações estas totalmente contestatórias à ideologia do Segundo Reinado. ${ }^{48}$

Distintamente do nativismo pernambucano, Varnhagen compreendia a guerra contra os holandeses sob a expectativa da construção do Estado imperial, "de cuja futura unidade ele teria constituído o primeiro elo" ${ }^{49}$ Não é sem razão que tenha confessado que a guerra contra os holandeses produziu resultados benéficos para a nação..$^{50}$ Segundo Varnhagen, um dos efeitos positivos do embate foi a promoção da civilização nas capitanias do Norte

\footnotetext{
${ }^{47}$ Idem, p.502.

${ }^{48}$ MELLO, Evaldo Cabral de. Rubro Veio: o imaginário da restauração pernambucana. $2^{\circ}$ ed. Rio de Janeiro: Topbooks, 1997. p.368. Vale ressaltar, ainda, que, antes mesmos do nativismo pernambucano do século XIX, já havia uma certa produção regional do século XVIII, de caráter memorialístico, que relacionava a história da dominação holandesa, especialmente, os episódios de sua expulsão, ao berço da nacionalidade, pela ideia de resistência e confronto. O exemplo mais conhecido dessa produção é o livro Desaggravos do Brasil e Glorias de Pernambuco, de Domingos do Loreto Couto, publicado em 1757.

${ }^{49}$ Ibidem., p.369.

${ }^{50}$ VARNHAGEN, Francisco Adolfo. História Geral do Brazil. op. cit., p.42.
} 
e do Sul do Brasil.$^{51}$ Em relação às capitanias do Norte, a civilização teria se constituído a partir do próprio contato dos holandeses com as populações locais. Conforme Varnhagen, os batavos, pertencentes a uma nação mais ativa e industriosa, encarregaram-se de levar a civilização para o Norte do Brasil, trazendo energia e atividade aos povos "entorpecidos pela incúria, a preguiça e o ilhamento". ${ }^{52}$ Enquanto no Sul, o processo teria sido derivado da presença holandesa. Dito de outro modo, com a interrupção do comércio de escravos entre Brasil e África, devido à ação dos holandeses na América, o Sul recebeu menos escravos negros do que antes, fato este interpretado por Varnhagen como sendo positivo para a evolução civilizatória da nação. ${ }^{53}$ Instigados pela falta de mão de obra escrava, os bandeirantes percorreram o interior para capturar indígenas, abrindo novos territórios durante a guerra..$^{54}$ Desse modo, nesse período beligerante, os holandeses no Norte e os bandeirantes no Sul e no interior levaram a civilização para o território do Brasil. ${ }^{55}$ É importante destacar que a civilização é um marco importante da tradição do iluminismo português, na qual Varnhagen estava inserido intelectualmente. ${ }^{56}$ Conforme Manoel Luiz Salgado Guimarães, o conceito de civilização era seminal no discurso do iluminismo e, igualmente, caro à historiografia de Varnhagen. ${ }^{57}$ Não é sem razão o seu interesse em interpretar a guerra contra os holandeses como uma das evidências do rumo civilizador da nação brasileira iniciado desde o período colonial.

Para Varnhagen, a guerra estranha, e não o domínio batavo em si, tinha possibilitado também o desenvolvimento da solidariedade entre as classes e as etnias que habitavam a colônia: "o perigo commum fez aproximar mais do escravo o senhor, e o soldado europeu do brazileiro, ou do índio amigo". ${ }^{58} \mathrm{~A}$ guerra contra o chamado inimigo comum permitiu a constituição de certo grau de tolerância e de fraternidade entre os povos das distintas capitanias espalhadas pelo Brasil, desenvolvendo um espírito público generalizado por toda a

\footnotetext{
${ }^{51}$ Ibidem, p.43.

${ }^{52}$ Ibidem, p.43

${ }^{53}$ GUIMARÃES, Manoel Luiz Salgado. Historiografia e nação no Brasil: 1838-1857. Rio de Janeiro: EdUERJ. 2011. p.216.

${ }^{54}$ Ibidem, p.216-216.

${ }^{55}$ VARNHAGEN, Francisco Adolfo. História Geral do Brazil. op. cit., p.43.

${ }^{56}$ GUIMARÃES, Manoel Luiz Salgado. Historiografia e nação no Brasil. op. cit., p.206.

${ }^{57}$ Ibidem, p.204.

${ }^{58}$ VARNHAGEN, Francisco Adolfo. História Geral do Brazil. op. cit., p.43.
} 
nação. ${ }^{59}$ Assim sendo, a guerra contra os batavos instigou entre os patrícios um espírito de unidade e integração nacional em prol da causa da Pátria. Consoante a interpretação de Porto Seguro, foi graças à fraternidade das etnias e das classes, perante o poder dos holandeses, que a verdadeira nacionalidade brasileira surgiu.$^{60}$ Foi essa nacionalidade, crioula e cristã, existente antes mesmo da Independência do Brasil e da formação do Estado nacional que "alentou e eletrisou os corações dos que ficárão vencedores em Guararápes" ${ }^{61}$ Como já foi dito, a obra da guerra contra os batavos foi interpretada por Varnhagen como um passo decisivo rumo à civilização e à constituição da nacionalidade brasileira. ${ }^{62} \mathrm{Com}$ seus escritos sobre a guerra contra os holandeses, Varnhagen ensejava se contrapor ao discurso regionalista e separatista, tão comum entre alguns homens de letras pernambucanos do oitocentos. Varnhagen oferece uma leitura inversa do nativismo pernambucano: em vez da manifestação do espírito regionalista, a guerra contra os holandeses assegurou a constituição da integridade nacional e o desenvolvimento da nacionalidade brasileira, elementos tão requeridos pelo projeto identitário e político do estado monárquico.

Foi a partir da leitura da Histórias do Brasil de Varnhagen que Augusto Tavares de Lyra interpretou os efeitos da guerra contra os holandeses. A expressão sentimento de nacionalidade é devedora dessa historiografia. É claro que, ao lado do fundamento historiográfico, o ambiente nacionalista também favoreceu a compreensão da guerra flamenga como uma propulsora da nacionalidade brasileira.

Além dos efeitos positivos da guerra, Augusto Tavares de Lyra destacou os motivos que levaram à dominação holandesa. As disputas religiosas e, sobretudo, o interesse econômico explicam a vinda dos holandeses ao Brasil, segundo Augusto Tavares de Lyra. Quanto ao aspecto religioso, o historiador norte-rio-grandense evidencia que as guerras entre católicos e protestantes na Europa, durante o século XVII, instigaram nos holandeses um espírito hostil, traduzido em interesses econômicos pelas possessões ultramarinas, tanto de Portugal como da Espanha. ${ }^{63}$ Dessa forma, a luta religiosa explicaria, em parte, a disposição dos holandeses em adotar uma política dominadora nos territórios ibéricos. Afirmamos "em parte", uma vez que os elementos

\footnotetext{
${ }^{59}$ Ibidem, p.43

${ }^{60}$ VARNHAGEN, Francisco Adolfo. Como se deve entender a nacionalidade na historia do Brasil. In: Anuário do Museu Imperial. Petrópolis. Número 9. 1948. p. 234.

${ }^{61}$ Ibidem, p.234

${ }^{62}$ GUIMARÃES, Manoel Luiz Salgado. Historiografia e nação no Brasil. op. cit., p.217

${ }^{63}$ LYRA, Augusto Tavares de. Dominio Hollandez no Brasil. op. cit., p.441.
} 
econômicos aparecem na narrativa de Augusto Tavares de Lyra como sendo as principais razões do interesse holandês pelo Brasil.

Para Augusto Tavares de Lyra, apesar do progresso da liberdade civil e intelectual da Pátria, durante a estadia holandesa, os flamengos "jámais tiveram outros propositos que não fossem os de salvaguardar os seus interesses commerciaes". ${ }^{64}$ Portanto, era o espírito mercantil que os animava a conquistar as possessões do Oriente e da América, especialmente o Brasil. ${ }^{65}$ Conforme o intelectual potiguar, a criação da Companhia das Índias Ocidentais e a prática da rapinagem eram evidências claras do interesse econômico dos holandeses em ocupar o território brasileiro: "Isto e a pirataria, em larga escala. Nada mais". ${ }^{66}$ Inclusive, a invasão ao Rio Grande [do Norte] é explicado, em grande medida, pelo interesse holandês em se apossar dos campos de criação de gado existentes na capitania para abastecer a população de Pernambuco, onde estava sediado o governo central. ${ }^{67}$

Se o econômico explica, por um lado, a motivação da invasão, por outro, elucida o horror da conquista e suas consequências nefastas para a população colonial. A invasão holandesa de interesse privado e econômico traduzia, na prática, em atos de violência e de rapinagem, segundo Tavares de Lyra. ${ }^{68}$ Essa leitura não era novidade, já havia sido construída desde o século XIX, inclusive, por historiadores pernambucanos de vertente nativista, como José Bernardo Fernandes Gama.

O grande drama da invasão em Pernambuco e no Rio Grande [do Norte] é narrado por Augusto Tavares de Lyra sob o signo da violência, da intolerância e da rapinagem. Segundo ele, a conquista significou uma tirania militar "que devia opprimir mais tarde a pequena população de colonos existente, dizimando-a em horríveis carnificinas, depois de despojal-a, pelo sangue e pelo roubo, de seus poucos haveres". ${ }^{69}$ Intolerância, desumanidade e tirania, longe de serem meras caracterizações da conquista, são conceitos que traduzem uma maneira de conceber e de interpretar o acontecimento histórico. Fica claro na narrativa de Augusto Tavares de Lyra como os holandeses deveriam ser vistos na memória histórica da nação.

\footnotetext{
${ }^{64}$ Idem, p.442.

${ }^{65}$ Idem, p.442

${ }^{66} \mathrm{Idem}, \mathrm{p} .443$.

${ }^{67}$ Idem, p.486.

${ }^{68}$ Idem, p.486

${ }^{69}$ Idem, p.463.
} 
Em relação especificamente ao Rio Grande [do Norte], Augusto Tavares de Lyra adiciona aos horrores da conquista a participação dos ferozes índios janduys, habitantes do sertão da capitania. ${ }^{70} \mathrm{O}$ letrado norte-rio-grandense coloca lado a lado o par holandeses-janduys como integrantes do plano de dominação. Augusto Tavares de Lyra não elucida as motivações dos janduys no processo de conquista. A penas ressalta o auxílio desses índios do sertão na obra dos holandeses que, impulsionados pela sua própria barbaria e selvageria, acabava por imitar a abominada atrocidade da invasão. ${ }^{71} \mathrm{O}$ uso desses conceitos evidencia a construção pejorativa e negativa da imagem dos índios janduys na narrativa de Tavares de Lyra. Contudo, o letrado potiguar fez questão de salientar que nem todos os índios que habitavam o Rio Grande [do Norte] estiveram ao lado dos holandeses. Ao narrar a tomada do Forte dos Reis Magos e a conquista de Natal, em 1633, pelas tropas holandesas sob o comando de von Ceulen, Augusto Tavares de Lyra destaca a condescendência dos chefes dos índios potiguares em auxiliar a resistência dos portugueses. ${ }^{72}$ Fica nítida a disposição dos personagens na narrativa da invasão. De um lado, holandeses e janduys como representantes da conquista e, de outro, índios potiguares e portugueses como sinônimos de resistência.

O contraponto da narrativa da rapinagem e da violência da conquista holandesa é a resistência dos antepassados. A estes são conferidos os adjetivos da coragem e do heroísmo. Mathias de Albuquerque é narrado como o personagem central da primeira resistência à invasão a Pernambuco. É interessante destacar que no imaginário nativista pernambucano, dos séculos XVIII e XIX, a figura de Mathias de Albuquerque foi excluída da tetrarquia dos heróis da guerra flamenga. Segundo Evaldo Cabral de Mello, a exclusão de Mathias de Albuquerque é explicada pela sua relação com a guerra da resistência, isto é, a guerra perdida, por essa razão sua presença no panteão dos heróis não foi possível: "A lista canônica preferiu os restauradores, vale dizer, os que tinham comandado a guerra vitoriosa, muito embora todos os tetrarcas tivessem participado, em diferentes graus, da resistência". ${ }^{73}$ Todavia, em textos posteriores, como a obra de Rocha Pombo ${ }^{74}$ e o próprio artigo de Augusto Tavares de Lyra, Mathias de Albuquerque desponta como um dos heróis da guerra contra os holandeses. Em se tratando do artigo de Augusto Tavares de Lyra em parti-

\footnotetext{
${ }^{70}$ Idem, p.461.

${ }^{71}$ Idem, p.461-462.

${ }^{72}$ Idem, p.460.

${ }^{73}$ MELLO, Evaldo Cabral de. Rubro veio. op. cit., p.197-198.

${ }^{74}$ POMBO, Rocha. História do Estado do Rio Grande do Norte. Rio de Janeiro: Annuário do Brasil, 1922.
} 
cular, é válido mencionar que o autor, especificamente, quando se refere à participação de Mathias de Albuquerque na defesa da Paraíba e do Rio Grande, adiciona o sobrenome Maranhão ao nome de Mathias de Albuquerque. Esse acréscimo, apenas presente quando se refere à presença do português no Rio Grande, diz respeito ao interesse de Augusto Tavares de Lyra em evidenciar a ancestralidade da família Albuquerque Maranhão, da qual fazia parte, na construção da memória histórica da luta contra os holandeses. É como se desde o período colonial os Albuquerque Maranhão estivessem presentes na memória nacional e norte-rio-grandense.

Em contraposição à figura heroica de Mathias de Albuquerque Maranhão, Augusto Tavares de Lyra destaca a covardia e a traição de Domingos Fernandes Calabar. Tal leitura acerca de Calabar era bastante recorrente entre os letrados brasileiros do século XIX. A ideia da deserção de Calabar foi um dos poucos pontos em comum entre os historiadores pernambucanos do oitocentos e Varnhagen. ${ }^{75}$ Contudo, alguns intelectuais, como Goetz de Carvalho, já ensaiavam, no final do século XIX e início do XX, uma reabilitação da imagem de Calabar, defendendo-o, inclusive, como um protopatriota. ${ }^{76}$ O próprio Tavares de Lyra reagiu a esse tipo de reinterpretação da figura de Calabar. Este é descrito como um sujeito incapaz de agir por amor à Pátria. Nesse sentido, qualquer consideração que o colocasse como um aspirante aos interesses da nação seria uma opinião errada, consoante Tavares de Lyra. ${ }^{77}$ Apesar de descrevê-lo como um mulato inteligente e audaz, Calabar é caracterizado como um personagem sem moral e sem cultura, logo não poderia agir impulsionado por sentimentos nobres e por amor à grandeza da sua terra: "Na melhor hypothese, era um aventureiro sem idéaes e sem principios. Seu procedimento é injustificavel, porque, além do mais, era militar e desertou de sua bandeira, á sombra da qual servia já desde $1630 " .{ }^{78}$ Calabar é colocado como o anteposto da figura do herói, ele é o traidor da nação. Tampouco contribuiu para a resistência, antes, favoreceu a causa dos holandeses, transformando o rumo dos acontecimentos. ${ }^{79}$

O par conquista/resistência ainda ganha outro cenário na narrativa de Augusto Tavares de Lyra: o interior da capitania do Rio Grande. Segundo

\footnotetext{
${ }^{75}$ Ibidem, p.401.

${ }^{76}$ Ibidem, p.400-408. Conferir também: MELLO, Evaldo Cabral de. Nassau. São Paulo: Companhia das Letras, 2006.

${ }^{77}$ LYRA, Augusto Tavares de. Dominio hollandez. op. cit., p.451.

${ }^{78}$ Idem, p.451

${ }^{79}$ Idem, p.451
} 
o historiador norte-rio-grandense, depois de tomar o Forte dos Reis Magos e a cidade do Natal, os holandeses voltaram-se para a conquista do interior. ${ }^{80}$ Com supostos surtos de inenarrável vandalismo, os holandeses, auxiliados pelos índios janduys, destruíram os dois únicos engenhos existentes na capitania e os principais núcleos de povoamento, Ferreiro Torto e Cunhaú..$^{81} \mathrm{O}$ uso do termo vandalismo faz parte do repertório de conceitos depreciativos relacionados à conquista holandesa no Rio Grande. Nesse aspecto, o termo vandalismo une-se a outros conceitos, como rapinagem, violência, intolerância e tirania, todos eles organizando uma narrativa que insiste em interpretar a invasão como sendo estritamente danosa para a formação da capitania do Rio Grande e para o Brasil.

A despeito de todo horror da conquista batava, há apenas um aspecto positivo da experiência holandesa no Brasil: o governo de Nassau. Segundo Augusto Tavares de Lyra, a administração do príncipe Nassau iniciou no Brasil uma era de desenvolvimento material e reconstrução política "cuja alta capacidade e superior descortino se devem, por excepção, durante o dominio hollandez, serviços realmente valiosos" ${ }^{82}$ Para ele, a administração nassoviana foi "um clarão de aurora na noite de despotismo e anarchia" que estava sobre o Brasil holandês "entregue ás explorações e instinctos mercantilistas de dominadores tyranos" ${ }^{83}$ Em contraposição à caracterização extremamente negativa do domínio batavo, tirano e vândalo, a experiência de Nassau no poder é descrita como um período de generosidade e de incentivo à atividade intelectual e aos "emprehendimentos fecundos", que "falam ao espirito e ao coração, dentro da ordem e no remanso da paz". ${ }^{44}$ Para Tavares de Lyra, o governo de Nassau era uma exceção dentro do quadro geral do domínio holandês. Desse modo, sua narrativa evidencia um fosso moral, intelectual e político entre Nassau e os outros holandeses envolvidos no domínio e o governo nassoviano e o restante da administração batava. Essa forma de ler a experiência nassoviana no Brasil era um lugar comum entre os letrados brasileiros do século XIX e início do XX, tanto aqueles vinculados ao IHGB como ao discurso nativista pernambucano. Aliás, no próprio manuscrito do Valeroso Lucideno (1648) de Manoel Calado Salvador, já havia uma narrativa voltada para o engrandecimento e humanização de Nassau, bem como a dicotomia entre a ação do príncipe e o comportamento dos outros administradores holandeses. ${ }^{85}$

\footnotetext{
${ }^{80}$ Idem, p.460.

${ }^{81}$ Idem, p.463.

${ }^{82}$ Idem, p.468.

${ }^{83}$ Idem, p.469.

${ }^{84}$ Idem, p.469

${ }^{85}$ MELLO, Evaldo Cabral de. Rubro Veio. op. cit., p.331.
} 
De acordo com Evaldo Cabral de Mello, a oposição entre o governo de Nassau e a administração dos outros holandeses no Brasil marcou fortemente a historiografia nativista até Fernandes Gama. ${ }^{86}$ Para este, Nassau deveria ter sido "o fundador de um Império mais permanente" ${ }^{87}$ Conforme Fernandes Gama, a obra do príncipe foi marcada pela prosperidade material e artística em Pernambuco, pois tinha a lembrança de uma administração "suave, e benéfica e que os povos tiveram que chorar a sabedoria do seu governo" ${ }^{88}$ Em contraposição, logo após a sua retirada, o domínio holandês no Brasil já não conseguia reproduzir o sucesso do governo do príncipe, redundando em sua iminente decadência. ${ }^{89} \mathrm{Na}$ narrativa de Fernandes Gama, fica clara a compartimentação entre a figura do príncipe Nassau e o Brasil holandês..$^{90}$ Este era sinônimo de rapinagem e de violência, seu veredito, portanto, é negativo, enquanto o governo de Nassau traduziria a generosidade e a "grandeza de que déra exemplo". ${ }^{91}$ Francisco Adolfo Varnhagen também partilhava da interpretação que distinguia o governo de Nassau e o restante da experiência holandesa no Brasil. Para ele, a Companhia das Índias Ocidentais teria acertado na escolha de Nassau como chefe do Brasil holandês. ${ }^{92}$ Nassau é caracterizado como ilustre, distinto, chefe hábil e prudente, merecedor de "um especial logar na historia da civilisação do nosso territorio". ${ }^{93}$ Não é por acaso que Varnhagen teceu comentários elogiosos à obra de Nassau no Brasil, especialmente em Pernambuco. Conforme o Visconde de Porto Seguro, o príncipe holandês realizara feitos consideráveis e habilmente executados, desde a construção de obras públicas à produção artística..$^{94}$ Todas essas obras, segundo ele, tinha a marca da boa administração e se enquadrariam no livro de civilização de um país. ${ }^{95}$

Como se percebe, a dicotomia entre o período nassoviano e a experiência do domínio holandês era um traço comum na historiografia brasileira

\footnotetext{
${ }^{86}$ Ibidem, p.331

${ }^{87}$ GAMA, José Bernardo Fernandes. Memorias historicas da provincia de Pernambuco. Tomo II. Recife: Tipografia de M. F. de Faria. 1844.p.22.

${ }^{88}$ Ibidem, p.114.

${ }^{89}$ Ibidem. p.114-145.

${ }^{90}$ MELLO, Evaldo Cabral de. Rubro Veio. op. cit., p.359.

${ }^{91}$ GAMA, José Bernardo Fernandes. Memorias historicas da provincia de Pernambuco. op. cit., p.114.

${ }_{92}$ VARNHAGEN, Francisco Adolfo. História Geral do Brazil. op. cit., p.375.

${ }^{93}$ Ibidem, p.375

${ }^{94}$ Ibidem, p.383-385.

${ }^{95}$ Ibidem, p.383.
} 
oitocentista. Do discurso nativista de Fernandes Gama às considerações de Varnhagen, o governo de Maurício de Nassau era interpretado como uma exceção ao domínio holandês. Augusto Tavares de Lyra esteve totalmente inserido nessa maneira de pensar o passado. Seu texto obedece às linhas gerais da análise dicotômica da experiência holandesa no Brasil.

Logo após o relato sobre o governo de Nassau e sua demissão da chefia do Brasil holandês em 1644, Augusto Tavares de Lyra dedica-se ao segundo movimento de resistência, encabeçado por João Fernandes Vieira, Henrique Dias, Vidal de Negreiros e Felipe Camarão. Em geral, o texto historiográfico de Tavares de Lyra divide-se em três momentos: a invasão inicial e o processo de conquista, o governo de Nassau e sua demissão e a última resistência ao domínio holandês e a sua consequente expulsão. Os relatos da invasão inicial e do governo neerlandês pós-Nassau possuem o mesmo contraponto: a questão da resistência. Em ambos há a evidência do sentimento de nacionalidade. Todavia, os personagens e o resultado são diferentes.

Como foi dito alhures, Augusto Tavares de Lyra elege como principal personagem da luta contra a invasão e a conquista batava Mathias de Albuquerque excluído da tetrarquia imaginária instituída pelo movimento nativista pernambucano do oitocentos. Entretanto, em relação ao governo holandês pós-Nassau, Tavares de Lyra elenca outros protagonistas da resistência: João Fernandes Vieira, Henrique Dias, Vidal de Negreiros e Felipe Camarão. A primeira onda de resistência tem como resultado o malogro diante do domínio holandês. 0 segundo movimento é descrito por Tavares de Lyra como iminente e inexorável: "ella é caudal avassaladora e cresce e avoluma-se e alastra-se, impetuosa e irresistivel". ${ }^{96}$ Seu resultado é positivo, pois consegue restaurar o domínio português no Brasil. Para o letrado potiguar, a principal causa das vitórias dos patriotas é o "sentimento de desaffronta nacional" ${ }^{97}$ É este que unifica os esforços e direciona a vontade dos patriotas para o serviço de "uma mesma aspiração", despertando " a confiança e assegura o apoio de toda a colonia". ${ }^{98}$ Como se pode notar, a leitura é a mesma do primeiro momento da resistência. O inimigo comum desperta o senso da unidade nacional e da fraternidade entre as classes. O escopo de Tavares de Lyra é evidenciar o sentimento de nacionalidade como o fio condutor de toda a lógica da luta no Brasil holandês.

A mesma semântica pode ser vista pelo episódio dos massacres das populações de Uruassú e Cunhaú, adjacentes à cidade do Natal, em 1645. Nesses

\footnotetext{
${ }^{96}$ LYRA, Augusto Tavares de. Dominio Hollandez. op. cit., p.479.

${ }^{97}$ Ibidem, p.480.

${ }^{98}$ Ibidem, p.480
} 
dois núcleos concentravam-se as mais expressivas populações do Rio Grande [do Norte], além da presença dos principais engenhos da capitania. De acordo com Augusto Tavares de Lyra, na parte Sul do Brasil holandês, o movimento de resistência tinha logrado, a partir de 1644, sucessivas vitórias. No entanto, ao Norte, onde estava situada a capitania do Rio Grande, a luta contra os holandeses teve uma dinâmica diferente: "a adversidade esmaga, em penosas provações, os portuguezes". ${ }^{99}$ Especialmente na capitania do Rio Grande [do Norte], Augusto Tavares de Lyra relata mais ondas de atrocidades cometidas pelos holandeses e os índios aliados nas populações de Uruassú e Cunhaú em resposta à resistência ocorrida no Sul do Brasil holandês: "ao descerem do Rio Grande do Norte, iniciam as suas tropelias pela matança de Cunhaú”. ${ }^{100} \mathrm{O}$ historiador norte-rio-grandense transcreve ipsis litteris o relato do massacre contido em um trecho do manuscrito Castrioto Lusitano (1679) do padre Rafael de Jesus. É válido ressaltar que era muito comum aos literatos e historiógrafos brasileiros do século XIX o uso dos relatos de viajantes e cronistas do seiscentos e do setecentos, em suas narrativas. ${ }^{101}$ Tavares de Lyra repetiu essa mesma prática da operação historiográfica brasileira oitocentista.

Conforme a narrativa do padre Rafael de Jesus, Jacobo (Jacob Rabbi) e os índios inimigos dos portugueses entraram no povoado de Cunhaú afixando nas portas das igrejas um edital que convocava todos para participar da missa a ser realizada no domingo. Na ocasião da missa, os índios, com Jacob Rabbi, assassinaram os colonos que ali estavam. ${ }^{102}$ Ao relatar o momento do massacre, Rafael de Jesus confere um sentido religioso ao acontecimento, especialmente em relação às atitudes confessionais dos moradores de Cunhaú presentes na igreja. Segundo o padre católico, diante das espadas dos bárbaros, restaram aos moradores católicos o pedido de perdão dos pecados e a oração a Deus. ${ }^{103}$ É patente o uso da imaginação e de elementos ficcionais no relato do padre católico. Rafael de Jesus adiciona ao seu relato elementos da ficção para construir uma cena própria de um martírio católico. O seu lugar confessional traduz-se na construção de um relato que confere aos personagens uma atitude característica da fé católica. A centralidade da narrativa mescla

\footnotetext{
${ }^{99}$ Ibidem, p.481.

${ }^{100}$ Ibidem, p.481

${ }^{101}$ Conferir: CEZAR, Temístocles. Quando um manuscrito torna-se fonte histórica: as marcas de verdade no relato de Gabriel Soares de Sousa (1587). Ensaio sobre uma operação historiográfica. História em Revista. Pelotas, v. 6, p. 37-58, 2000. SÜSSEKIND, Flora. O Brasil não élonge daqui: o narrador, a viagem. São Paulo: Companhia das Letras, 1990. p.54.

${ }^{102}$ Rafael de Jesus apud LYRA, Augusto Tavares de. Dominio Hollandez. op. cit., p.482.

${ }^{103}$ Idem, p.482
} 
a atrocidade dos índios e dos holandeses com as demonstrações da confissão religiosa. É dessa chave de leitura que Augusto Tavares de Lyra se apropria em sua explanação. No entanto, é válido destacar que a descrição da atrocidade e da carnificina de Cunhaú estava presente também em outros relatos historiográficos. Baseados em cronistas, Fernandes Gama, Varnhagen, Oliveira Lima e Rocha Pombo consideravam a atitude de Jacob Rabbi e dos índios aliados como uma expressão da violência e do massacre aos moradores de Cunhaú. ${ }^{104}$ As historiografias oitocentista e novecentista reproduziram as descrições dos manuscritos do século XVII. Nesse sentido, o relato matança de Cunhaú era um lugar comum entre os historiadores brasileiros contemporâneos a Augusto Tavares de Lyra.

O relato de Uruassú não destoa do episódio de Cunhaú. Segundo o historiador norte-rio-grandense, ao chegarem a Uruassú, em outubro de 1645, os holandeses e os índios aliados obrigaram os moradores pacíficos a se despir e a se pôr de joelhos:

Comprehendendo, então, estes martyres ter chegado o seu fim, obedeceram com grande paciencia e resignação, erguendo os olhos ao céo, despedindo-se mutuamente, fazendo actos de devoção, declarando de morrerem todos na fé catholica, apostolica, romana, e recusando com firmeza e ministerio de um predicante heretico que se apresentou. Indignados com isto, os protestantes deram a todos taes tormentos que, para os padecentes, a morte já era mercê. ${ }^{105}$

Novamente o texto historiográfico de Tavares de Lyra evidencia um relato de violência e, mais uma vez, aos holandeses e aos índios aliados são destinados o papel do horror e da atrocidade. Em contraste com a figura violenta dos índios e dos batavos, os moradores são descritos como pacíficos. Uma verdadeira narrativa da diferença é operada por Augusto Tavares de Lyra nessa descrição. Além de pacíficos, os moradores são caracterizados como católicos e mártires, em contraposição aos holandeses, protestantes e heréticos. O texto em questão expressa uma linguagem que privilegia conceitos estritamente da esfera religiosa. Nesse sentido, a morte ou o martírio

\footnotetext{
${ }^{104}$ Conferir: GAMA, José Bernardo Fernandes. Memorias historicas da provincia de Pernambuco. op. cit.; VARNHAGEN, Francisco Adolfo de. História das Lutas Contra os Holandeses no Brasil desde 1624 a 1651. $1^{\mathrm{a}}$ Ed. Viena: Imp. de Carlos Finsterback, 1871; LIMA, Oliveira. Pernambuco, seu desenvolvimento histórico. Leipzig: F.A Brochaus. 1895; POMBO, Rocha. História do Brasil. Volume I. Rio de Janeiro; São Paulo; Porto Alegre: W. M. Jackson INC. 1959.
}

${ }^{105}$ LYRA, Augusto Tavares de. Dominio Hollandez. op. cit., p.484. 
dos moradores de Uruassú aparece como uma demonstração do amor e da devoção à fé católica. ${ }^{106}$ Contudo, é preciso destacar que a ideia do mártir não se apresenta deslocada da figura do patriota. Conforme Tavares de Lyra, os moradores morreram igualmente pela pátria ${ }^{107} \mathrm{~A}$ pátria não se refere ao Estadonacional brasileiro, até mesmo porque essa noção era inexistente durante o período colonial, mas, sim, a semântica vinculada ao território que os antigos habitantes da capitania do Rio Grande residiam, isto é, o significado aí diz respeito à dimensão local e não nacional. ${ }^{108}$ Contudo, há uma engenharia na narrativa de Tavares de Lyra.

Em primeiro lugar, é preciso ressaltar que a palavra pátria aparece nos manuscritos, nas crônicas dos padres católicos, que Tavares de Lyra utilizou em seu texto. Em relação ao sentido do conceito de pátria nos manuscritos dos séculos XVII, é possível que haja duas possibilidades semânticas: a) como sendo o território habitado pelos colonos da capitania do Rio Grande, o local do seu nascimento; ou b) alusivo ao domínio português como um todo. Partimos da hipótese de que o primeiro sentido seja o mais preciso, tendo em vista que a ideia de pátria estaria mais próxima da noção de local de nascimento, a província de origem, e não de um domínio territorial maior e mais abrangente, como o reino de Portugal. ${ }^{109} \mathrm{Em}$ segundo lugar, Tavares de Lyra ressignificou o sentido de pátria dos manuscritos para acomodá-lo (conectá-lo) à noção de

\footnotetext{
${ }^{106}$ Nos anos 30, a intelectualidade católica norte-rio-grandense apropriou-se da ideia dos mártires de Cunhaú e Uruassú para construir a sua identidade religiosa no Rio Grande do Norte. Sobre esse assunto, conferir os seguintes artigos: PEIXOTO, Renato Amado. Duas Palavras: Os Holandeses no Rio Grande e a invenção da identidade católica norte-rio-grandense na década de 1930. Revista de História Regional, v. 19, p. 35-57, 2014 e PEIXOTO, Renato Amado. Por Deus, pela Pátria e pelo Rei - Os Holandeses no Rio Grande e a fabricação dos conceitos acerca do espaço na década de 1930. Revista de História Regional, v. 20, p. 398-414, 2016. ${ }^{107}$ LYRA, Augusto Tavares de. Dominio Hollandez. op. cit., p.485.

${ }^{108}$ Para uma maior compreensão acerca das noções de pátria, nação e Estado, conferir o texto do historiador português Fernando Catroga, disponível no seguinte site: http://www.humanas.ufpr.br/portal/cedope/ files/2011/12/P\%C3\%A1tria-e-Na\%C3\%A7\%C3\%A3o-Fernando-Catroga.pdf

${ }^{109}$ Essa menção aos adjetivos pátrios, às vezes tomados como sinônimos, relaciona-se com a politização das identidades regionais, já presentes nas últimas décadas do setecentos, e com os discursos em torno da ideia de Pátria que parecem ter adquirido um estatuto, com a emergência de uma identidade política, a partir de 1817, em Pernambuco. Nesse contexto, os termos, pátria e Pátria, minúscula e maiúscula, não significariam a mesma coisa e não estariam, necessariamente, associados à ideia de nação - quase absolutamente ausente no vocabulário político dos discursos da Revolução de 1817. A Pátria, portanto, referia-se à nação, "pois propunha uma imaginação coletiva da soberania", enquanto a pátria estava associada à dimensão mais regional, ao local de nascimento, a província de origem. JANCSÓ, István; PIMENTA, João Paulo G. Peças de um mosaico (ou apontamentos para o estudo da emergência da identidade nacional brasileira). In: MOTA, Carlos Guilherme (organizador). Viagem incompleta. A experiência brasileira. Formação: histórias. São Paulo: Editora Senac São Paulo, 1999; BERBEL, Márcia. Pátria e patriotas em Pernambuco (1817-1822): nação, identidade e vocabulário político. In: JANCSÓ, István (org.) Brasil: Formação do Estado e da Nação. São Paulo: Hucitec; Ed. Unijuí; Fapesp, 2003.
} 
Nação. $O$ intelectual norte-rio-grandense constrói a narrativa a partir de um jogo semântico urdido pelo emprego da expressão nossos antepassados, evidenciando um elo entre passado e presente. Isso significa dizer que, embora os mártires de Uruassú tenham agido por amor a sua pátria, ao local do seu nascimento, eles carregariam uma espécie de origem sacralizada do sentimento e do pertencimento nacional. É como se os habitantes da capitania do Rio Grande já guardassem a semente de uma comunidade demográfica e territorial que iria desabrochar-se no futuro com a emergência do Estado-nação. Essa operação semântica faz parte dos discursos nacionalistas, tão em voga no contexto pós-Guerra, que se caracterizaram justamente por construírem o elo entre pátria e nação, bem como entre passado e presente. Com isso, Augusto Tavares de Lyra quer fazer crer que os moradores da capitania do Rio Grande estavam lutando não só pela sua pátria, seu território, sua comunidade local, mas também pela Nação que haveria de surgir. Essa estratégia discursiva era fundamental para o intelectual norte-rio-grandense, afinal importava construir um lugar para o Rio Grande do Norte na memória nacional.

Enquanto os antepassados da capitania do Rio Grande são qualificados como devotos, mártires e patriotas, os holandeses são descritos como aqueles que lutam apenas pelos seus interesses econômicos, como destaquei anteriormente. É a necessidade de importação de gado para a região do Recife que explica, para o historiador norte-rio-grandense, as horríveis carnificinas no Rio Grande. ${ }^{110}$ É por causa desse motivo que os batavos procuravam apavorar, com exemplos de crueldade inigualáveis, os portugueses, reinóis ou não, que viviam na capitania: "Seriam assim senhores daquellas paragens e ficariam livres, embora por algum tempo, de uma concorrencia impertinente e incommoda". ${ }^{111} \mathrm{O}$ colono da capitania é caracterizado de maneira distinta. Este resiste e morre por amor à fé católica e pela pátria. Estas estão inseridas no mesmo plano, na narrativa de Tavares de Lyra. Ambas denotam a resistência contra os holandeses. A fé e a pátria são alçadas como conceitos que implicam uma oposição ao outro, ao estrangeiro, dominador e protestante, daí o interesse de Tavares de Lyra de colocá-los lado a lado.

A narrativa do massacre de Cunhaú e Uruassú é uma forma de evidenciar a contribuição do Rio Grande [do Norte] na resistência contra o holandês: "nem se explicaria por outra fórma que, ao mesmo tempo que anniquilavam uma população que começava a desenvolver-se, mantivessem fortes elementos

\footnotetext{
${ }^{110}$ LYRA, Augusto Tavares de. Dominio Hollandez. op. cit., p.486.

${ }^{111}$ Idem, p.486
} 
de resistencia na capitania". ${ }^{112}$ Tais episódios permitiam apontar a "simples participação do Rio Grande do Norte no dominio hollandez". ${ }^{113}$ Desse modo, a narrativa dos mártires contribuía para a urdidura de um lugar para o Rio Grande do Norte na memória histórica da nação. Isso explica a razão do destaque dado por Tavares de Lyra à referida descrição. As populações de Cunhaú e Uruassú eram tipologias dos patriotas brasileiros. Eram evidências da origem do sentimento de nacionalidade do país. Por meio do relato dos mártires o Rio Grande [do Norte] conecta-se ao tempo da nação.

Na narrativa dos mártires nenhum personagem é destacado. A ideia dos mártires é descrita como um coletivo singular, referindo-se ao conjunto de resistentes como um todo, e não como uma personalidade. Apenas Felipe Camarão é retratado como o grande herói potiguar da luta contra os holandeses. ${ }^{114}$

Depois de narrar cronológica, linear e detalhadamente as marchas e as contramarchas da expulsão dos holandeses do Rio Grande [do Norte], Augusto Tavares de Lyra finaliza o seu texto avaliando os efeitos da presença batava como um todo no Brasil e, em particular, na capitania. Primeiramente, Tavares de Lyra parte de uma questão: se o Brasil tivesse sido conquistado primitivamente por outro povo, no caso, pelos holandeses, teria tido uma sorte diferente? ${ }^{115}$ Sua resposta é categórica: "não cremos que melhor tivesse sido o nosso futuro". ${ }^{116} \mathrm{O}$ historiador norte-rio-grandense argumenta que, ao chegarem ao Brasil, os holandeses encontraram uma colônia em franco desenvolvimento, proporcionado pelo trabalho da colonização portuguesa. ${ }^{117}$ Ademais, todos os alicerces da vida sociocultural já estavam firmes e qualquer colonização posterior redundaria necessariamente em uma ação perturbadora. Conforme Tavares de Lyra, se os holandeses tivessem logrado êxito no domínio definitivo do Brasil, tal efeito não seria obra de uma ação colonizadora, mas, sim, imperialista. ${ }^{118}$ É interessante destacar que a geração de Augusto Tavares de Lyra vivenciou a experiência do neocolonialismo nos continentes da África e da Ásia. Em um artigo publicado pela RRN, em 1898, intitulado Política Internacional Americana, Augusto Tavares de Lyra já havia

\footnotetext{
${ }^{112}$ Idem, p.486

${ }^{113}$ SEGUNDA E ÚLTIMA SESSÃO PLENA EM 15 DE SETEMBRO DE 1914. In: Revista do Instituto Histórico e Geográfico Brasileiro. Rio de Janeiro. Parte I. Tomo especial. 1915. p.128.

${ }^{114}$ LYRA, Augusto Tavares de. Dominio Hollandez. op. cit., p.499.

${ }^{115}$ Idem, p.505.

${ }^{116} \mathrm{Idem}, \mathrm{p} .505$

${ }^{117}$ Idem, p.505

${ }^{118}$ Idem, p.505
} 
se posicionado totalmente contrário às posturas imperialistas dos países europeus nos mencionados continentes. Para ele, a política de conquista e de expansão colonial no oitocentos era causa dos maiores desastres políticos e sociais da sua contemporaneidade, criando, entre as diversas nações, ódios e rivalidades que, "quase sempre, lhes têm acarretado guerras sanguinolentas em que mal se calculam os sacrificios de vidas e de dinheiro". ${ }^{119}$ Nesse sentido, se a colonização holandesa, de fato, tivesse se concretizado, deveria ser comparada com a experiência imperialista do seu tempo presente, a qual interpretava negativamente.

Para desqualificar uma possível pressuposição positiva da colonização holandesa no Brasil, Augusto Tavares de Lyra argumentava que os neerlandeses não produziram resultados satisfatórios para a nação. ${ }^{120}$ Embora tenha listado algumas realizações significativas do governo de Nassau para o Brasil, Augusto Tavares de Lyra considerava tal administração como uma exceção dentro do conjunto do domínio holandês, por isso seria um erro compará-la com a prática colonizadora dos portugueses. ${ }^{121}$ Ele compreendia que os processos usados pelos governos da metrópole lusitana eram limitados, no entanto os métodos colonizadores dos intrusos "não lhe eram superiores". ${ }^{122}$ Como se pode observar, novamente, Augusto Tavares de Lyra argumenta a partir da comparação. Os holandeses sempre são descritos sob o signo da inferioridade, quando comparados aos portugueses: "o paralelo é inteiramente desfavoravel aos hollandezes". ${ }^{123}$ Segundo Tavares de Lyra, estes nada fizeram enquanto povo colonizador, o que poderia ser atestado pela obra negativa em suas próprias colônias: "Basta olhar para Java com a sua população dividida em castas e transformada em campo de exploração, donde se drenam para a Europa as suas riquezas". ${ }^{124}$ Diferentemente do resultado negativo da colonização holandesa, os portugueses, espanhóis e ingleses, ao contrário, ofereceram à América a fusão de raças diversas, nações novas "para a vida da civilização e da liberdade". ${ }^{125}$ A colonização holandesa é descrita sob o signo da negatividade, marcada pela sua esterilidade em formar novos povos,

\footnotetext{
${ }^{119}$ LYRA, Augusto Tavares de. Politica Internacional Americana. In: Revista do Rio Grande do Norte. Número 10. Natal. 1898. Tipografia d' A República, p.533.

${ }^{120}$ LYRA, Augusto Tavares de. Dominio Hollandez no Brasil. op. cit., p.505

${ }^{121}$ Idem, p.505.

${ }^{122}$ Idem, p.505

${ }^{123}$ Idem, p.505

${ }^{124}$ Idem, p.505

${ }^{125}$ Idem, p.505
} 
em contrapartida as experiências colonizadoras dos países ibéricos e da Inglaterra são consideradas em sua positividade, justamente por possibilitar o surgimento de novos países.

Fica evidente que em termos comparativos, para Tavares de Lyra, a colonização portuguesa era superior à experiência colonizadora neerlandesa. Essa forma de ver a questão já havia sido objeto de polêmica entre os historiadores brasileiros do oitocentos.

Imerso na querela da colonização portuguesa e holandesa, Augusto Tavares de Lyra considerava a primeira, a despeito das suas limitações e falhas, superior à segunda. Por essa razão, relativizou os possíveis melhoramentos materiais legados pelos invasores. Para ele, tais medidas foram quase nulas para o Rio Grande [do Norte], perceptíveis apenas em Recife "onde tudo que se fez foi devido á iniciativa pessoal de Nassau". ${ }^{126}$ Em outras localidades, como o Rio Grande [do Norte], os traços e os vestígios da passagem ou permanência neerlandesa "não ficaram assignalados sinão pela reconstrucção de fortes ou por algumas obras de defesa". ${ }^{127}$ Tavares de Lyra enfatiza a nulidade do legado holandês no Rio Grande [do Norte] afirmando que em Natal "nada existe do tempo dos hollandezes; alli apenas fizeram concertos e reparos no Forte dos Reis". ${ }^{128}$

Em relação ao restante da capitania, a constatação era a mesma: "Existirá, porventura, alguma cousa no interior? Também não". ${ }^{129}$ Segundo Tavares de Lyra, o interior da capitania foi o palco de violência e devastação dos holandeses. ${ }^{130}$ Os núcleos de população mais importantes da capitania, onde estavam localizados os engenhos Cunhaú e Ferreiro Torto, atestariam o "theatro de innomináveis carnificinas" e indescritíveis devastações: "não passavam, por fim, de monções de ruinas". ${ }^{131}$ Todo o legado holandês no Rio Grande [do Norte] é narrado sob o signo da violência. Tavares de Lyra põe em suspeição, ainda, as possíveis contribuições neerlandesas para o desenvolvimento material da capitania. Para ele, as velhas muralhas da lagoa de Guaraíras e a ponte de Extremoz, construídas pelos invasores, não visavam ao melhoramento estrutural da capitania, mas, sim, atendiam aos próprios interesses bélicos dos holandeses. Desse modo, Augusto Tavares de Lyra minimiza o possível legado

\footnotetext{
${ }^{126}$ Idem, p.505

${ }^{127}$ Idem, p. 505

${ }^{128}$ Idem, p.505

${ }^{129}$ Idem. p.505.

${ }^{130}$ Idem. p.505-506.

${ }^{131}$ Idem, p.505
} 
batavo: "Afóra isto, não resta nem mesmo a noticia de quaisquer outros melhoramentos effectuados pelos intrusos". ${ }^{132}$ Até mesmo as descobertas das salinas de Mossoró e de Macau, ocorridas nas primeiras expedições neerlandesas ao interior da capitania, comandadas por Gedeon Morris e Smient, foram descritas como contribuições modestas e improfícuas, primeiro, porque os próprios portugueses já haviam tomado conhecimento das regiões salineiras e, segundo, por representar os interesses da Companhia das Índias Ocidentais "cuja politica na America foi sempre a de locupletar-se com o labor extranho, sem preparar vantagens futuras. Assim foi tudo e por toda parte". ${ }^{133}$

Embora o legado holandês tenha sido relatado como improfícuo e modesto, Tavares de Lyra compreendia que, do ponto de vista étnico, os neerlandeses teriam contribuído para a formação étnica do tipo sertanejo do Rio Grande do Norte. O resultado desse cruzamento seria constatado na própria característica física das populações sertanejas do Rio Grande do Norte. Augusto Tavares de Lyra corroborava também a referida tese: “Talvez esteja mesmo no maior cruzamento então operado entre elles e os indios a explicação para a differença de typo que, não raro, se observa entre os sertanejos e os habitantes do litoral norte-rio-grandense". ${ }^{134}$ Segundo Tavares de Lyra, a presença de homens alourados, fortes e de olhos azuis e de crianças louras e de "inquietos olhos de côr de saphira", relato atestado por aqueles que viajavam pelo interior do estado, era uma evidência da herança holandesa na formação étnica da população do sertão do Rio Grande do Norte. ${ }^{135}$

\section{Conclusão}

Ao publicar o artigo Domínio Holandez no Brasil, especialmente no Rio Grande do Norte, Tavares de Lyra estava convicto de que sua missão nacionalista havia sido cumprida: honrou a Pátria escrevendo sobre o seu passado, ou melhor, a pátria e a Pátria. É nesse sentido que Tavares de Lyra compreendia, por exemplo, a ação dos chamados patriotas de Cunhaú e Uruassú, uma vez que estes teriam devotado a sua vida à causa pátria, estaria indicando que seus compatriotas estavam defendendo a soberania da nação a partir de sua pátria particular, a capitania do Rio Grande [do Norte]. De certa maneira, Tavares de Lyra repetia o gesto dos seus supostos patrícios do passado. Apesar de não

\footnotetext{
${ }^{132}$ Idem, p.506.

${ }^{133}$ Idem, p. 505

${ }^{134}$ Idem, p. 504-505.

${ }^{135}$ Idem, p.504-505
} 
ser um mártir, o gesto de escrever história é concebido também como um ato patriótico. Quando Tavares de Lyra escreve sobre a sua pátria, o Rio Grande do Norte, mais especificamente acerca do domínio holandês na capitania, ele o faz crendo que está honrando a nação, a Pátria.

Decerto, Tavares de Lyra construiu uma leitura assaz depreciativa em relação à experiência neerlandesa no Brasil, mais especificamente na capitania do Rio Grande. A depreciação da figura do holandês e a exaltação dos colonos que habitavam a capitania faziam parte da leitura da história construída sob o signo do nacionalismo, tão em voga nos anos 10. Nesse sentido, o texto de Tavares de Lyra seguiu a orientação geral do PCNH.

No que tange à historiografia norte-rio-grandense, sua maneira de narrar o acontecimento contribuiu para a formação de uma dada representação do passado do Rio Grande do Norte. O texto de Tavares de Lyra tornou-se referência para outros estudos referentes ao domínio holandês no Rio Grande [do Norte]. Mais do que isso, a partir do seu artigo, Tavares de Lyra construiu não só uma dada forma de ler a história do seu estado, mas, sobretudo, pôde urdir uma narrativa comprometida em evidenciar a participação do Rio Grande do Norte em um dos considerados principais acontecimentos históricos do Brasil. Desse modo, o relato sobre o domínio holandês se constituiu como uma estratégia, uma vez que conectou o tempo do Rio Grande do Norte ao tempo da nação. Não é por acaso o título do artigo: "Domínio Hollandez no Brasil, especialmente no Rio Grande do Norte. Isso significa dizer que Tavares de Lyra lia a história nacional a partir do Rio Grande do Norte. Dito de outro modo, investigar o passado não era apenas honrar a nação, era uma forma de assinalar o lugar do Rio Grande do Norte na memória histórica nacional.

\section{Referências}

BERBEL, Márcia. Pátria e patriotas em Pernambuco (1817-1822): nação, identidade e vocabulário político. In: JANCSÓ, István (org.) Brasil: Formação do Estado e da Nação. São Paulo: Hucitec; Ed. Unijuí; Fapesp, 2003.

BUENO, Almir de Carvalho. Visões de República: ideias e práticas políticas no Rio Grande do Norte (1880-1895). Natal: EDUFRN, 2002.

CEZAR, Temístocles. Quando um manuscrito torna-se fonte histórica: as marcas de verdade no relato de Gabriel Soares de Sousa (1587). Ensaio sobre uma operação historiográfica. História em Revista. Pelotas, v. 6, p. 37-58, 2000. 
COSTA, Bruno Balbino Aires da Costa. "A casa da memória norte-rio-grandense”: o Instituto Histórico e Geográfico do Rio Grande do Norte e a construção do lugar do Rio Grande do Norte na memória nacional (1902-1927). Tese (Doutorado em História) - Programa de Pós-graduação em História, Universidade Federal do Rio Grande do Sul, Porto Alegre. 2017

COSTA, Regina de Carvalho Ribeira da. O paradigma das "invasões holandesas": a interpretação de Francisco Adolfo de Varnhagen. Revista do Instituto Histórico e Geográfico Brasileiro, Rio de Janeiro, a.180 (480): 91-120, 2019

GAMA, José Bernardo Fernandes. Memorias historicas da provincia de Pernambuco. Tomo II. Recife: Tipografia de M. F. de Faria. 1844.

GOMES, Ângela de Castro. A República, a História e o IHGB. Belo Horizonte: Argvmentvm, 2009.

GUIMARÃES, Lúcia Maria Paschoal. Primeiro Congresso de História Nacional: breve balanço da atividade historiográfica no alvorecer do século XX. Tempo. Revista do Departamento de História da UFF, Niterói (RJ), v. 9, n.18, 2005.

. Da escola palatina ao silogeu: Instituto Histórico e Geográfico Brasileiro (18891938). Rio de Janeiro: Museu da República, 2007.

HRUBY, Hugo. Obreiros diligentes e zelosos auxiliando no preparo da grande obra: a História do Brasil no Instituto Histórico e Geográfico Brasileiro (1889-1912). Dissertação (Mestrado em História). Faculdade de Filosofia e Ciências Humanas, PUCRS. Porto Alegre. 2007

JANCSÓ, István; PIMENTA, João Paulo G. Peças de um mosaico (ou apontamentos para o estudo da emergência da identidade nacional brasileira). In: MOTA, Carlos Guilherme (organizador). Viagem incompleta. A experiência brasileira. Formação: histórias. São Paulo: Editora Senac São Paulo, 1999

MELLO, Evaldo Cabral de. Rubro Veio: o imaginário da restauração pernambucana. 2º ed. Rio de Janeiro: Topbooks, 1997.

. Nassau. São Paulo: Companhia das Letras, 2006.

OLIVEIRA, Lúcia Lippi. A questão nacional na Primeira República. São Paulo: Editora Brasiliense, 1990

POMBO, Rocha. História do Estado do Rio Grande do Norte. Rio de Janeiro: Annuário do Brasil, 1922.

. História do Brasil. Volume I. Rio de Janeiro; São Paulo; Porto Alegre: W. M. Jackson INC. 1959. 
PEIXOTO, Renato Amado. Espacialidades e estratégias de produção identitária no Rio Grande do Norte no início do século XX. In: PEIXOTO, Renato Amado (org.). Nas trilhas da representação: trabalhos sobre a relação entre história, poder e espaços. Natal: EDUFRN, 2012.

. Duas Palavras: Os Holandeses no Rio Grande e a invenção da identidade católica norte-rio-grandense na década de 1930. Revista de História Regional, v. 19, p. 35-57, 2014

. Por Deus, pela Pátria e pelo Rei - Os Holandeses no Rio Grande e a fabricação dos conceitos acerca do espaço na década de 1930. Revista de História Regional, v. 20, p. 398-414, 2016.

RICCEUR, Paul. Tempo e narrativa. A intriga e a narrativa histórica. Volume 1. São Paulo: Editora WMF Martins Fontes, 2010.

RODRIGUES, José Honório. Historiografia e bibliografia do domínio holandês no Brasil. Rio de Janeiro: Departamento de Imprensa Nacional. 1949.

SÜSSEKIND, Flora. O Brasil não élonge daqui: o narrador, a viagem. São Paulo: Companhia das Letras, 1990

GUIMARÃES, Manoel Luiz Salgado. Historiografia e nação no Brasil: 1838-1857. Rio de Janeiro: EdUERJ. 2011

LIMA, Oliveira. Pernambuco, seu desenvolvimento histórico. Leipzig: F.A Brochaus. 1895

VARNHAGEN, Francisco Adolfo. História Geral do Brazil. Tomo segundo. Rio de Janeiro: E. e H. Laemmert, 1857.

. História das Lutas Contra os Holandeses no Brasil desde 1624 a 1651. $1^{\mathrm{a}}$ Ed. Viena: Imp. de Carlos Finsterback, 1871

. Como se deve entender a nacionalidade na história do Brasil. In: Anuário do Museu Imperial. Petrópolis. Número 9. 1948.

VISCARDI, Cláudia Maria Ribeiro. 0 teatro das oligarquias: uma revisão da "política do café com leite". 2.ed. Belo Horizonte: Fino Traço, 2012.

WASSERMAN, Cláudia. Percurso Intelectual e Historiográfico da Questão nacional e Identitária da América Latina: as condições de produção e o processo de repercussão do conhecimento histórico. In: Revista Anos 90, Porto Alegre, n.18, dezembro de 2003. 